Bangladesh J. Zool. 40(2): 231-239, 2012

\title{
PREVALENCE AND COMPARATIVE LIKELIHOOD OF URINARY TRACT INFECTION (UTI) AMONG FEMALE OUT PATIENTS IN BSMMU
}

\author{
Hamida Khanum*, Fahmida Munir, A. Z. M. Shafiullah ${ }^{1}$ and Farhana Muznebin \\ Department of Zoology, University of Dhaka, Dhaka-1000, Bangladesh
}

\begin{abstract}
Out of 200 urine samples of female out patients from BSMMU hospital, $128(64 \%)$ cases were detected as Escherichia coli positive, 66.67\% of cases in summer and $60 \%$ in winter. To compare the risks of $E$. coli infection in summer and winter and also among different age groups, odd ratio (OR) and relative risk (RR) were used as measures of comparative likelihood. The values of both OR and $\mathrm{RR}$ were greater than one when the risk of $E$. coli infection of adults (16-35) was compared with that of middle age (36-50) and old age (51-70) groups. The adults were always at higher risk of UTI by $E$. coli, and the livelihood of infection was not equal in summer and winter.
\end{abstract}

Key words: Escherichia coli, urinary tract, prevalence, risk ratio, odd ratio.

\section{INTRODUCTION}

Infection of the urinary tract is an extremely common clinical problem (Lambaie and Davison 1978). Even today urinary tract infection (UTI) is one of the most important causes of morbidity and mortality in the developing countries like Bangladesh. This may be attributed to lack of proper research, faulty diagnostic procedures, abuse of chemotherapeutic agents of the people and little or no preventive measures. The alarming phenomenon is that UTI does not restrict itself to the urinary tract only rather it can spread. UTI infections usually cause inflammation of the affected tissues of the urethra (urethritis) and urinary bladder. The most significant danger from lower urinary tract infections is that they can affect the kidney (causing pyelonephritis) and develop bladder infections subsequently (Nahar et al. 2010). Bacteria carried by blood stream can also infect the kidney and the infections can be very difficult to eradicate, are often chronic, and lead to marked damage of the kidney. Death promptly follows kidney failure unless the patient is lucky enough to be able to use artificial kidneys, or perhaps to receive a kidney transplant.

The most common aerobic members causing UTI are Escherichia coli, Klebsiella sp., Enterobacter sp., Pseudomonas sp., and Proteus sp. Other bacteria, such as Staphylococcus saprophyticus occasionally appear in spontaneous urinary infection. It has been observed that only a small number of serologically

*Author for correspondence. ${ }^{1}$ Department of Statistics, Biostatistics and Informatics, University of Dhaka, Dhaka-1000, Bangladesh. 
distinct strains are responsible for the infections caused by E. coli. It has been observed that the greater dominance of $E$. coli in outpatient population are serologically distinct strains responsible for the UTI.

Recurrent or persistent of UTI patient with lower urinary tract involvement tend to have repeated bouts of transient symptomatic or asymptomatic infection. Many investigators in Bangladesh also showed that women were the usual victims of the urinary pathogens. Haque et al. (1976) reported $78.8 \%$ of the $E$. coli infection in women. Nahar and Selim (1989) worked on adult women and reported that $70.9 \%$ organisms were found to be E. coli. E. coli was the predominant organism during pregnancy and was prevalent for six months after delivery in about a $1 / 3^{\text {rd }}$ of the pregnant patients (Nahar et al. 2010, Khanum et al. 2006).

In the present paper, the prevalence of UTI was studied among the female out patients of the Bangabandhu Sheikh Mujib Medical University (BSMMU) Hospital.

\section{MATERIAL AND METHODS}

Sources of specimens: Urine specimens were collected from the BSMMU Hospital, Dhaka during the period from June 2008 to August 2009.

Urine examination: A fresh drop of uncentrifuged urine was placed on a slide, covered with a cover slip and examined with restricted light intensity under the high dry objective of an ordinary clinical microscope.

Culture of urine: A sample of the urine was streaked across the surface of one or more agar plates and placed in an incubator at body temperature for 24 hours. If $E$. coli was present, the total number of bacteria was counted (colony count), and the organisms were identified by additional biochemical tests.

Estimation: 1. Prevalence - prevalence of health-related state in a statistical population is defined as the total number of cases of the risk factor in the population at a given time, or the total number of cases in the population, divided by the number of individuals in the population Then, we can write the prevalence as

$$
\text { Prevalence }=\frac{a}{a+b} \times 100 .
$$

where $a=$ Total number of cases (positive), $b=$ Total number of non cases (negative).

2. Odds - probability theory and statistics, where the variable $p$ is the probability in favor of the event, and the probability against the event is 
therefore 1- $p$, "the odds" of the event are the quotient of the two, or $\frac{p}{1-p}$. The value may be regarded as the relative likelihood of the event that will happen, expressed as a fraction (if it is less than 1), or a multiple (if it is equal to or greater than one) of the likelihood that the event will not happen.

3. Odds ratio $(\mathrm{OR})$ and Relative risk/Risk ratio $(\mathrm{RR})$ : Both the odds ratio and the relative risk compare the likelihood of an event between the following two groups of pathogens.

\begin{tabular}{lccc}
\hline & E. coli positive & E. coli negative & Total \\
\hline Summer & $a$ & $b$ & $a+b$ \\
Winter & $c$ & $d$ & $c+d$ \\
\hline Total & $a+c$ & $b+d$ & $n$ \\
\hline
\end{tabular}

where, $a=$ No. of $E$. coli positive in summer, b= No. of $E$. coli negative in summer, c= No. of $E$. coli positive in winter, $\mathrm{d}=$ No. of $E$. coli negative in winter.

Now, the odds ratio for summer with respect to winter =Odds in favor of $E$. coli positive in summer/ Odds in favor of $E$. coli positive in winter. That is, $O R=\frac{a / b}{c / d}$. This mean summer season has $O R=\frac{a / b}{c / d}$ greater odds of $E$. coli positive than winter season. The relative risk (sometimes called the risk ratio) compares the probability of $E$. coli positive in each season. Relative risk for summer= Probability of $E$. coli positive in summer/probability of $E$. coli positive in winter. That is, $R R=\frac{a / a+b}{c / c+d}$. This means in summer a patient has $R R=\frac{a / a+b}{c / c+d}$ times greater probability of being $E$. coli positive than the probability in winter.

\section{RESULTS}

A total of $128(64 \%)$ urine samples was detected by the presence of E. coli positive while $72(36 \%)$ cases were found negative (Table 1). During summer, the prevalence of $E$. coli was $73.33 \%$ in June, $55 \%$ in July and $70 \%$ in August (Fig. 1). During winter, the prevalence of positive cases was $66.67 \%$ in November, $50 \%$ in December and $61.54 \%$ in January (Table 1). During the study period of six months, the highest prevalence of E. coli infection was in June 2008.

Prevalence of E. coli in relation to age groups (during summer season): In the study population, the females were categorized into three broad age groups, viz. adult (16-35 year), middle age (36-50 year) and old age (51-70 year).

In summer, $69.23 \%$ of adults, $66.67 \%$ of middle aged and $62.50 \%$ of old patients were exposed to $E$. coli causing UTI. The prevalence was highest $(80 \%)$ 
Table 1. Prevalence of UTI positive and negative during the study period.

\begin{tabular}{llcccccccc}
\hline Season & Month & $\begin{array}{c}\text { Total } \\
\text { patients }\end{array}$ & $\begin{array}{c}\text { Positive } \\
\text { results }\end{array}$ & $\begin{array}{c}\text { Preva- } \\
\text { lence (\%) }\end{array}$ & $\begin{array}{c}\text { Negative } \\
\text { results }\end{array}$ & $\begin{array}{c}\text { Preva- } \\
\text { lence (\%) }\end{array}$ & Odds & OR & RR \\
\hline \multirow{3}{*}{ Summer } & June & 60 & 44 & 73.33 & 16 & 26.67 & 2.75 & & \\
& July & 40 & 22 & 55.00 & 18 & 45.00 & 1.22 & & \\
& August & 20 & 14 & 70.00 & 6 & 30.00 & 2.33 & & \\
& Total & 120 & 80 & 66.67 & 40 & 33.33 & 2.00 & & \\
\multirow{3}{*}{ Winter } & November & 30 & 20 & 66.67 & 10 & 33.33 & 2.00 & 1.33 & 1.11 \\
& December & 24 & 12 & 50.00 & 12 & 50.00 & 1.00 & & \\
& January & 26 & 16 & 61.54 & 10 & 38.46 & 1.60 & & \\
& Total & 80 & 48 & 60.00 & 32 & 40.00 & 1.50 & & \\
\hline Grand Total & $\mathbf{2 0 0}$ & $\mathbf{1 2 8}$ & $\mathbf{6 4 . 0 0}$ & $\mathbf{7 2}$ & $\mathbf{3 6 . 0 0}$ & $\mathbf{1 . 7 8}$ & & \\
\hline
\end{tabular}

OR = Odds Ratio; RR = Risk Ratio

among the patients aged between 16 and 20 years; lowest $(50 \%)$ in patients aged between 60 and 70 years. In winter, the prevalence was $73.33 \%$ among the adults, $61.54 \%$ in middle aged and $41.67 \%$ in old group (Table 3 ). The female patients of age between 16 and 20 showed the highest prevalence of $83.33 \%$ while the oldest patients aged between 66 and 70 showed $41.67 \%$.

Table 2. Age-based incidence of $E$. coli in summer.

\begin{tabular}{|c|c|c|c|c|c|c|c|c|c|}
\hline $\begin{array}{l}\text { Age group } \\
\text { (yr) }\end{array}$ & $\begin{array}{l}\text { Age } \\
\text { limits }\end{array}$ & $\begin{array}{c}\text { Total } \\
\text { patients }\end{array}$ & $\begin{array}{l}\text { Positive } \\
\text { results }\end{array}$ & $\begin{array}{c}\text { Prevalence } \\
(\%)\end{array}$ & $\begin{array}{l}\text { Negative } \\
\text { results }\end{array}$ & $\begin{array}{c}\text { Prevalence } \\
(\%)\end{array}$ & Odds & OR & $\mathrm{RR}$ \\
\hline \multirow{5}{*}{$\begin{array}{l}\text { Adult } \\
(16-35)\end{array}$} & $16-20$ & 10 & 8 & 80.00 & 2 & 20.00 & 4.00 & $\begin{array}{l}\text { Adult/ } \\
\text { Middle }\end{array}$ & $\begin{array}{l}\text { Adult/ } \\
\text { Middle }\end{array}$ \\
\hline & $21-25$ & 20 & 14 & 70.00 & 6 & 30.00 & 2.33 & 1.13 & 1.04 \\
\hline & $26-30$ & 12 & 8 & 66.67 & 4 & 33.33 & 2.00 & $\begin{array}{l}\text { Adult/ } \\
\text { Old }\end{array}$ & $\begin{array}{l}\text { Adult/ } \\
\text { Old }\end{array}$ \\
\hline & $31-35$ & 10 & 6 & 60.00 & 4 & 40.00 & 1.50 & 1.35 & 1.11 \\
\hline & Total & 52 & 36 & 69.23 & 16 & 30.77 & 2.25 & & \\
\hline \multirow{4}{*}{$\begin{array}{l}\text { Middle } \\
(36-50)\end{array}$} & $36-40$ & 12 & 8 & 66.67 & 4 & 33.33 & 2.00 & Middle / & Middle/ \\
\hline & $41-45$ & 14 & 10 & 71.43 & 4 & 28.57 & 2.50 & 0.89 & 0.96 \\
\hline & $46-50$ & 10 & 6 & 60.00 & 4 & 40.00 & 1.50 & $\begin{array}{c}\text { Middle / } \\
\text { Old }\end{array}$ & $\begin{array}{l}\text { Middle/ } \\
\text { Old }\end{array}$ \\
\hline & Total & 36 & 24 & 66.67 & 12 & 33.33 & 2.00 & 1.2 & 1.07 \\
\hline \multirow{5}{*}{$\begin{array}{l}\text { Old } \\
(51-70)\end{array}$} & $51-55$ & 10 & 6 & 60.00 & 4 & 40.00 & 1.50 & $\begin{array}{l}\text { Old/ } \\
\text { Adult }\end{array}$ & $\begin{array}{l}\text { Old/ } \\
\text { Adult }\end{array}$ \\
\hline & $56-60$ & 6 & 4 & 66.67 & 2 & 33.33 & 2.00 & 0.74 & 0.90 \\
\hline & $61-65$ & 8 & 6 & 75.00 & 2 & 25.00 & 3.00 & $\begin{array}{l}\text { Old/ } \\
\text { Middle }\end{array}$ & $\begin{array}{l}\text { Old/ } \\
\text { Middle }\end{array}$ \\
\hline & $66-70$ & 8 & 4 & 50.00 & 4 & 50.00 & 1.00 & 0.83 & 0.94 \\
\hline & Total & 32 & 20 & 62.50 & 12 & 37.50 & 1.67 & & \\
\hline \multicolumn{2}{|c|}{ Grand Total } & 120 & 80 & 66.67 & 40 & 33.33 & 2.00 & & \\
\hline
\end{tabular}

Although the results were different, the prevalence of the presence and absence of $E$. coli among different age groups were found uniform in summer 
and winter (Figs. 1 and 2). This is an indication that age groups and seasons might not be related to the prevalence of $E$. coli. However, the age of the patient and the season, in which urinary tract was infected, draw special attention as long as the presence of $E$. coli is concerned.

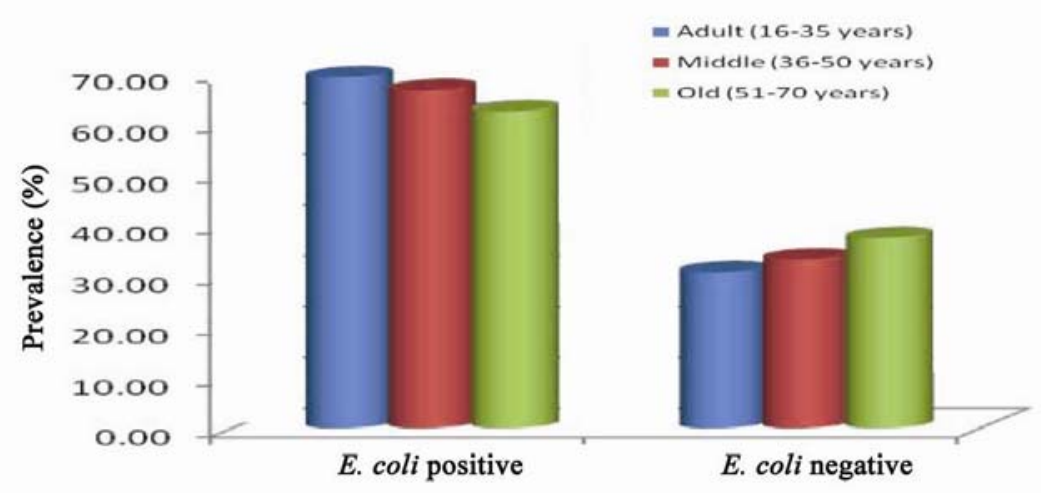

Fig. 1. Prevalence of $E$. coli infection of adult, middle aged and old female patients in summer.

Comparative likelihoods of finding E. coli using Odds ratio (OR) and Risk Ratio $(R R)$ : In the present study, it was found that the probability of a young female to be $E$. coli positive was higher than the probability of an old female. The last three columns of Tables 1, 2, 3 and 4 present these findings in terms of odds, odds ratio (OR) and risk ratio/relative risks (RR). The odds in favour of E. coli positive was maximum (2.75) in June and it was 1.00 in December (Table 1). In general the odds of being E. coli positive in summer was 2.0 and that in winter was 1.5 . Both OR (2.33) and RR (1.11), being greater than 1, reveal that the likelihood of finding E. coli was higher in summer than in winter. Comapred to different age groups using OR, it was observed that in summer adult patients had 1.13 fold greater odds of being $E$. coli positive than the middle aged group and they had 1.35 fold greater odds of being $E$. coli positive than the old group (Table 2). Middle aged group had 1.2 fold greater odds of being E. coli than the old group. In winter, the adult had 1.72 fold greater odds than middle aged and 3.85 fold greater odds than old age group; Middle age group had 2.24 fold greater odds than old age group (Table 3). Similar results were obtained when the comparative likelihood was studied with respect to relative risks (RR). In summer, the adult patients had 1.04 times greater probability of being $E$. coli positive $(R R=1.04)$ than the middle aged patients (Table 2).

In winter, adult patients had 1.19 times higher probability Risk Ratio $(R R=1.19)$ than the old patients (Table 3$)$. The adult patients in summer had 1.11 times higher probability $(\mathrm{R} R=1.11)$ to be $E$. coli positive than the old patients (Table 2). In winter it was found to be 1.76 (Table 3). When the middle 
aged group was compared with the old group, RR was 1.07 in summer (Table 2) and it was 1.48 in winter (Table 3). For the adult patients, RR was 0.94 which indicates that adult patients are 0.06 times less likely to be E. coli positive in

Table 3. Age based incidence of $E$. coli (winter).

\begin{tabular}{|c|c|c|c|c|c|c|c|c|c|}
\hline $\begin{array}{l}\text { Age group } \\
\text { (yr) }\end{array}$ & $\begin{array}{l}\text { Age } \\
\text { limits }\end{array}$ & $\begin{array}{l}\text { Total } \\
\text { Patients }\end{array}$ & $\begin{array}{l}\text { Positive } \\
\text { results }\end{array}$ & $\begin{array}{c}\text { Preva- } \\
\text { lence (\%) }\end{array}$ & $\begin{array}{l}\text { Negative } \\
\text { results }\end{array}$ & $\begin{array}{c}\text { Preva- } \\
\text { lence (\%) }\end{array}$ & Odds & OR & $\mathrm{RR}$ \\
\hline \multirow{5}{*}{$\begin{array}{l}\text { Adult } \\
(16-35)\end{array}$} & $16-20$ & 12 & 10 & 83.33 & 2 & 16.67 & 5.00 & $\begin{array}{l}\text { Adult/ } \\
\text { Middle }\end{array}$ & $\begin{array}{l}\text { Adult/ } \\
\text { Middle }\end{array}$ \\
\hline & $21-25$ & 8 & 6 & 75.00 & 2 & 25.00 & 3.00 & 1.72 & 1.19 \\
\hline & $26-30$ & 6 & 4 & 66.67 & 2 & 33.33 & 2.00 & $\begin{array}{l}\text { Adult/ } \\
\text { Old }\end{array}$ & $\begin{array}{l}\text { Adult/ } \\
\text { Old }\end{array}$ \\
\hline & $31-35$ & 4 & 2 & 50.00 & 2 & 50.00 & 1.00 & 3.85 & 1.76 \\
\hline & Total & 30 & 22 & 73.33 & 8 & 26.67 & 2.75 & & \\
\hline \multirow{4}{*}{$\begin{array}{l}\text { Middle } \\
(36-50)\end{array}$} & $36-40$ & 12 & 10 & 83.33 & 2 & 16.67 & 5.00 & $\begin{array}{l}\text { Middle/ } \\
\text { Adult }\end{array}$ & $\begin{array}{l}\text { Middle/ } \\
\text { Adult }\end{array}$ \\
\hline & $41-45$ & 8 & 4 & 50.00 & 4 & 50.00 & 1.00 & 0.58 & 0.84 \\
\hline & $46-50$ & 6 & 2 & 33.33 & 4 & 66.67 & 0.50 & $\begin{array}{l}\text { Middle / } \\
\text { Old }\end{array}$ & $\begin{array}{l}\text { Middle/ } \\
\text { Old }\end{array}$ \\
\hline & Total & 26 & 16 & 61.54 & 10 & 38.46 & 1.60 & 2.24 & 1.48 \\
\hline \multirow{5}{*}{$\begin{array}{l}\text { Old } \\
(51-70)\end{array}$} & $51-55$ & 8 & 4 & 50.00 & 4 & 50.00 & 1.00 & $\begin{array}{l}\text { Old/ } \\
\text { Adult }\end{array}$ & $\begin{array}{l}\text { Old/ } \\
\text { Adult }\end{array}$ \\
\hline & $56-60$ & 6 & 2 & 33.33 & 4 & 66.67 & 0.50 & 0.26 & 0.57 \\
\hline & $61-65$ & 6 & 2 & 33.33 & 4 & 66.67 & 0.50 & $\begin{array}{l}\text { Old/ } \\
\text { Middle }\end{array}$ & $\begin{array}{l}\text { Old/ } \\
\text { Middle }\end{array}$ \\
\hline & $66-70$ & 4 & 2 & 50.00 & 2 & 50.00 & 1.00 & 0.45 & 0.68 \\
\hline & Total & 24 & 10 & 41.67 & 14 & 58.33 & 0.71 & & \\
\hline \multicolumn{2}{|c|}{ Grand Total } & 80 & 48 & 60.00 & 32 & 40.00 & 1.50 & & \\
\hline
\end{tabular}

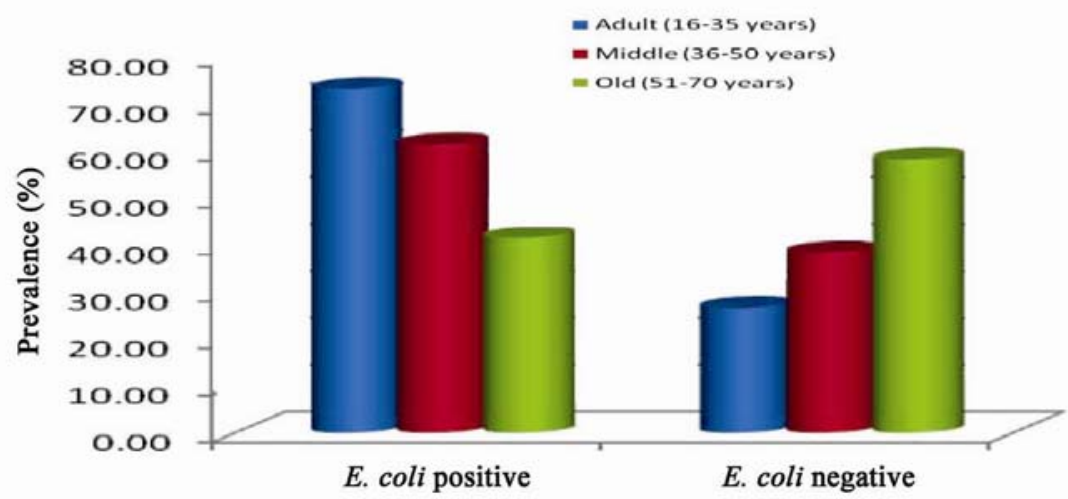

Fig. 2. Prevalence of $E$. coli infection of adult, middle aged and old female patients in winter.

summer than in winter. For middle aged patients $R R=1.08$ means $E$. coli in summer is 1.08 times more likely than in winter. For old patients $R R=1.5$ means. 
Table 4. Age and Season specific comparative likelihood of $E$. coli infection.

\begin{tabular}{|c|c|c|c|c|c|}
\hline Season & Age group (yr) & Age limits & $\begin{array}{l}\text { Odds of being } \\
\text { positive }\end{array}$ & $\begin{array}{l}\text { Risk ratio } \\
\text { by age group }\end{array}$ & $\begin{array}{l}\text { Risk ratio } \\
\text { by season }\end{array}$ \\
\hline \multirow{12}{*}{ Summer } & \multirow{5}{*}{ Adult (16-35) } & $16-20$ & 4.00 & Adult/Middle & \multirow[t]{2}{*}{ Summer/Winter } \\
\hline & & $21-25$ & 2.33 & 1.13 & \\
\hline & & $26-30$ & 2.00 & & 0.94 \\
\hline & & $31-35$ & 1.50 & Adult/Old & \\
\hline & & $16-35$ & 2.25 & 1.35 & \\
\hline & \multirow{3}{*}{ Middle (36-50) } & $36-40$ & 2.00 & Middle/Adult & \multirow[t]{2}{*}{ Summer/Winter } \\
\hline & & $41-45$ & 2.50 & 0.89 & \\
\hline & & $46-50$ & 1.50 & Middle/Old & \multirow[t]{2}{*}{1.08} \\
\hline & \multirow{6}{*}{ Old (51-70) } & $36-50$ & 2.00 & & \\
\hline & & $51-55$ & 1.50 & Old/Adult & \multirow[t]{2}{*}{ Summer/Winter } \\
\hline & & $56-60$ & 2.00 & 0.74 & \\
\hline & & $61-65$ & 3.00 & & \multirow[t]{3}{*}{1.5} \\
\hline \multirow{16}{*}{ Winter } & & $66-70$ & 1.00 & Old/Middle & \\
\hline & & $51-70$ & 1.67 & 0.83 & \\
\hline & \multirow{5}{*}{ Adult (16-35) } & $16-20$ & 5.00 & Adult/Middle & \multirow[t]{2}{*}{ Winter/Summer } \\
\hline & & $21-25$ & 3.00 & 1.72 & \\
\hline & & $26-30$ & 2.00 & & \multirow[t]{3}{*}{1.06} \\
\hline & & $31-35$ & 1.00 & Adult/Old & \\
\hline & & $16-35$ & 2.75 & 3.85 & \\
\hline & \multirow{4}{*}{ Middle (36-50) } & $36-40$ & 5.00 & Middle/Adult & \multirow[t]{2}{*}{ Winter/Summer } \\
\hline & & $41-45$ & 1.00 & 0.58 & \\
\hline & & $46-50$ & 0.50 & Middle/Old & \multirow[t]{2}{*}{0.92} \\
\hline & & $36-50$ & 1.60 & 2.24 & \\
\hline & \multirow{5}{*}{ Old (51-70) } & $51-55$ & 1.00 & Old/Adult & \multirow[t]{2}{*}{ Winter/Summer } \\
\hline & & $56-60$ & 0.50 & 0.26 & \\
\hline & & $61-65$ & 0.50 & & \multirow[t]{3}{*}{0.67} \\
\hline & & $66-70$ & 1.00 & Old/Middle & \\
\hline & & $51-70$ & 0.71 & 0.45 & \\
\hline
\end{tabular}

\section{DISCUSSION}

Mere presence of organisms in urine is not an adequate basis for the diagnosis of UTI (Kass 1975). Quantitative bacteriology is necessary and hence colony count is necessary to distinguish contamination from true infection particularly where mixed organisms are cultured. (Wemambu and Obi 1983), usually urinary tract infection is defined as the colonization and invasion of the structures in the urinary tract by microorganisms (Metha et al. 1981). The course of an infection is dependent on the ability of the pathogens to overcome the complex defense system of human body (Funfotuck et al. 1989).

In Bangladesh significantly higher number of $E$. coli is isolated from urine. The patients of UTI were found to posses hemolytic and hem agglutinating properties (Muhammad et al. 1990). The hospital environment in an important determinant of the nature of the bacterial flora in UTI. In this study, prevalence 
of $E$. coli in the urine samples was more in summer season than winter season because in summer season increased temperature causes sweating more than winter, therefore urine production becomes less and concentrated which provides the opportunity to multiply the bacteria. Conversely, in winter season less sweating causes more dilute urine production, which washes away any multiplying bacteria. Women of different age groups were observed to be very much prone to UTI. The highest numbers of positive cases were found among the adult women 16-20 yr group were $80 \%$ during summer and $83.33 \%$ also with the same age group, i.e. 16-20 yrs during winter season. UTI is always a very common infection among the women revealed by the studies of several workers.

Many investigators in Bangladesh also showed that women were the usual victims of the urinary pathogens. Haque et al. (1976) screened 170 volunteers of different sex and found 33 (19.4) positive cases. Among these 33 cases, 26 were female $(78.8 \%)$. The greater prevalence of UTI among the adult females is due to the vulnerable anatomical position of the short urethra, which easily admits bacteria from the vagina to the urinary bladder and others factors like hormonal secretion, sexual intercourse and pregnancy (Smith and Bullen 1965, and Kass 1975). From the present study it appears that the urinary tract infection is fairly common in the women. The study also finds that adult women are always in higher risk of being exposed to E. coli. infection than others. Unfortunately, in most of the cases the women are not aware of this problem and remain without proper laboratory investigation and treatment

The results of this study indicate $E$. coli is prevalent in women and it posses virulence associated properties. So appropriate measures should be taken for the detection and treatment of such cases.

\section{LITERATURE CITED}

FUNFOTUCK, R., TSCHAPE, H., STEIN, G., VOILANDIT, R. and SCHNEIDER S.S. 1989. Virulence of $E$. coli strain in relation to their hemolytic formation, mannose resistant hem agglutination, hydroxamate production. K-1-antigen and the plasmid profile in patients with xhronic pyelonephrities. Nephrol. 32: 178-183.

HAQUE, N., KIBRIA, G. and BEGUM, S.N. 1976. Prevalence of urinary tract infection in adult women. B.M.R.C. Bull. 2: 75-85.

KASS, E.H. 1975. Bacteriuria and the of diagnosis infections of the urinary tract. Arch Int. Med. 100: 709.

KHANUM, H., NAHAR, Z. and FARHANA, R. 2006. Occurrence of Escherichia coli infection. Bangladesh J. Zool. 34(1):181-186.

LAMBAEI, A.T. and DAVISON, A.M. 1978. Infection of the lower urinary tract. In Davidsons Principle and Practice of Medicine, 15th edition. ELBS/Churchill Livingstone, pp. 393-396. 
METHA, P.J., SHUTT, S.M. and KETHARI, P.K. 1981. Urinary tract infections. Ind Pract. 34: 705-709.

MUHAMMAD, F.K., RAHMAN, M., KISH, M.R.A. and HOSSAIN, T. 1990. Special properties associated with virulence of urinary Escherichia coli. B.M.R.C. Bull. 16: 26-33.

NAHAR, N., HUQ, F. and SELIM, K. 1989. Prevalence of bacteriuria in adult Bangladeshi Females Bang. J. Microbiol. 6(2): 37-42.

NAHAR, S.J., KHANUM, H. and SHIMUSAKI, K. 2010. Occurrence of Escherichia coli among the women of Dhaka city. ARPN J. Agri. And Bio. Sci. 5(6): 68-73.

SMITH, K.P. and BULLEN, M. 1965. Bacteriuria in pregnancy. Lancet 1: 395-399.

WEMAMBU, S.N. and OBI, J.O. 1983. Bacteriological profile and sensitivity pattern in childhood urinary tract infection in Benin City. J. Trop. Pedtr. 29: 44-46.

(Manuscript received on January 16, 2012; revised on December 28, 2012) 